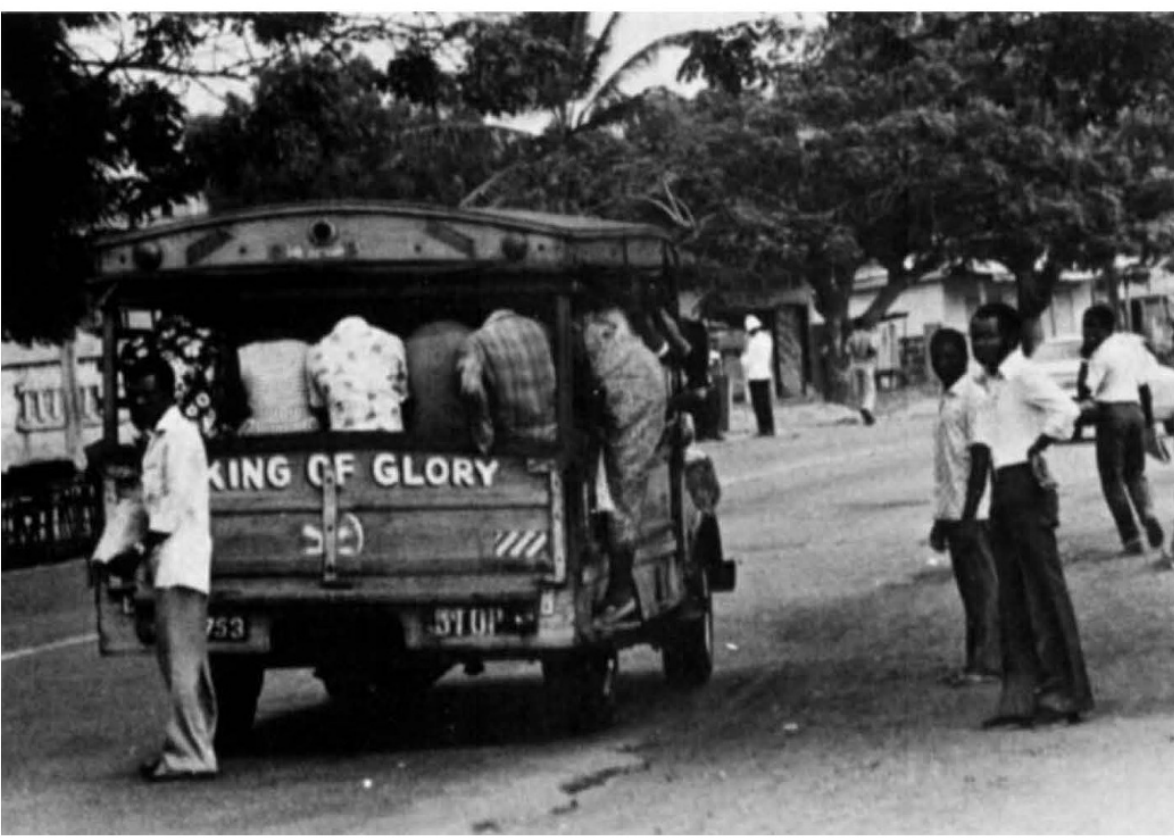

Fledgling transport systems could be hit by petrol shortages

help developing countries solve their own problems, he said; the only difference now is that the accent is more and more on solar power plants instead of nuclear plants.

"Often we do not even know whether immature energy technologies are being pushed upon us", Dr Meyer alleged. "And where we have developed technologies indigeneously, for instance, the production of alcohol from sugarcane, we find ourselves besieged with claims of patent infringements and demands for royalties."

Among alternate energy sources, discussions centred on wood, which provides over three-quarters of the Third World's population with its energy needs. For these people, the wood crisis is worse than the oil crisis, and certain to become even more acute. Kenyan experts revealed that wood scarcity in their country is already so acute that serious thought is being given to providing electricity for cooking in rural areas to replace the use of firewood. "Until 1973, we thought we had the wood problem licked", said India's energy planner Sankar. "We were subsidising the use of kerosene in villages to replace the use of firewood. But then in 1973 the carpet was pulled out right under out feet."

The answer is to grow more wood; but the forum discovered that first, scientists themselves do not have adequate knowledge about fast growing trees and forestry techniques, and second, even if existing knowledge could be applied right away, a British expert pointed out, it would be 1996 before rural areas could get wood. Problems of social organisation in Third World villages will prevent rapid diffusion of innovations. India's progress with biogas plants to meet rural cooking energy needs has also been very slow.

There was, however, total unanimity on the need for developing countries to plan their future energy use carefully and to discover new sources. Once developing countries identify their energy problems, and choose the technologies they want to solve them, then the developed countries can help them in developing those technologies instead of passing on to them packages that imitate successful ones in the West, said Professor Ignacy Sachs of the University of Paris.

However, the forum learnt that though very soon most Third World countries would be setting up ministries of energy, few of them had either the relevant information systems or the trained personnel with analytical capabilities to make proper economic, social and technical choices in the energy sector. It is here that developed countries and international organisations can help most, felt the Third World participants.

Professor M. S. Wionczek of Mexico suggested the establishment of an institute for advanced studies in energy policy, possibly similar to the Institute of Theoretical Physics at Trieste, a unique institution which provides scientists from developing countries an opportunity to meet and discuss with leading scientists, including Nobel laureates from developed countries. Venezuela's Minister of State for International Economic Affairs, $\mathrm{Mr}$ M. Perez-Guerrero, suggested a new institute be set up within the UN to help Third World countries in energy planning.

But there were no solutions to the problem that Third World experts had themselves identified: what do developing countries do to solve their energy problems in the immediate future? As India's Sankar put it: "I find no dearth of experts prepared to chart out an energy strategy for the year 2000. My problem, however, is 1980 and 1981 . Who will help me solve that?"

Anil Agarwal

\section{Experts agree on Mediterranean pollution treaty}

Scientists from 14 of the 18 Mediterranean states unexpectedly agreed last week on the text of a treaty to control land-based sources of pollution - but the rate of implementation of the treaty will depend on how fast scientific work can be completed.

"The deadlock is over"' said the director of the United Nations Environment Programme's regional seas unit, Stjepan Keckes, this week, "but it is not the breakthough that some newspapers have reported"'.

One of the main obstacles had been a disagreement between the northern, industrial nations, and the southern underdeveloped states, over whether to impose uniform emission standards on polluters, or to define common goals for coastal water quality. The underdeveloped states argued that the former would penalise the growth of new industry in an area which presently had little industry and little pollution; while the north contended that the latter would allow the south to develop cheap and heavily polluting industries which would compete with more expensively controlled northern firms. In the end the underdeveloped states won the argument, and the treaty specifies coastal water quality standards. "This is the most logical arrangement"' Keckes told Nature. "It is the same pragmatic scheme you operate in Britain".

The treaty will go to a specialist diplomatic meeting in Athens in April for signature. Ratification comes later.

"These are the first steps", said Keckes, a marine scientist who is also in charge of the scientific assessment of the state of the Mediterranean. "But we don't have enough evidence yet. We can define water quality for bathing, using a microbiological standard - we've been measuring on 150-200 beaches - and later we hope to define heavy metal limits for shellfish growing"' he said. "But the rate of implementation of the treaty will depend on how fast we can define stanards scientifically."

Progress is therefore limited by the money UNEP can spend on its pollution monitoring programme, 'Medpol'. Earlier this year, a full meeting of the contracting states voted to delete Medpol's air pollution research programme (see 15 February p 506) - whereas air. Keckes feels, may be the main source of the central Mediterranean's metallic pollution.

"The research programme needs an additional boost and additional money" said Keckes. He hopes to present a strong case for restarting the air pollution programme to the next full meeting of contracting states in February 1981.

Robert Walgate 